Central Europe, now more than two decades old, has resurfaced from several directions in recent months and would in principle make it possible to attain President Reagan's ideal zero option by other than bilateral negotiations. The snag (which does not attend all proposals for such zones) is that the effect of such a proposal would put the West at a serious disadvantage unless there were a more general and a substantial reduction of nuclear weapons everywhere - an objective still a long way off.

This is why the best outcome of the Stockholm meeting would be an agreement on two points - that there should be negotiations on nuclear weapons in general embracing both the START and intermediate-range missile talks and that all five declared nuclear powers, not just the biggest, should somehow take part. The case for dealing with other than strategic weapons is amply illustrated by the questions that have arisen during the past two years at Geneva. Are British and French nuclear weapons strategic, tactical or something else? Are aircraft capable of carrying nuclear weapons to be counted as if they were missiles? What about the devices euphemistically called battlefield weapons?

But would not the involvement of extra parties with such diverse interests merely complicate negotiations that are already difficult enough? That has been the conventional wisdom so far, and indeed there is every reason why the Soviet Union and the United States should be made to push ahead on START in the hope of getting some kind of agreement by 1985, when SALT II lapses automatically (and when the signatories of the NonProliferation Treaty will be asking what the nuclear powers have done about arms control). But it is also plain, from the disappointments at Geneva, that the variety of the means by which nuclear weapons can be delivered is now so great that the hope of negotiating separately on different systems - of agreeing on the trade-off between SS20 and Pershing II as if aircraft or artillery did not exist - is nugatory. Indeed, there is a good chance that the sheer diversity of interest of the three minor nuclear powers would be a help and not a hindrance, if only because the negotiations would then be less black-and-white. And they have one thing in common with the larger powers - all of them would prefer that nuclear weapons should be markedly reduced in number.

\section{Bombs are not new}

\section{$A B C$ 's horror film on nuclear war, should be shown until nobody is surprised.}

IN the long run, the success of arms control negotiations will be determined by what ordinary people think about the urgency of the cause, and by the way in which they convey to governments their opinions on what should be done. The reception last week in the United States of ABC television's film "The Day After" is, in this connection, depressing. The event was preceded by solemn warnings that children of a tender age (or indeed, any age) should not be allowed to watch the film without the presence of adults who might be able to comfort and explain. The United States Government also thought it proper that Mr George Shultz, the Secretary of State, should appear in public afterwards to promise that he and his colleagues are as surely against nuclear war as anybody else. The experience seems momentarily to have been cathartic for a large proportion of 250 million people - a proof that nuclear warfare would be both devasting and horrible.

But who ever thought that it could be otherwise? Since a decade after Hiroshima and Nagasaki, the nature of what would happen has been clear. This was the period when committees as different as those sponsored by the Government of India and the United Nations set about the grisly task of extrapolating from what was known of the effects of isolated 20 kiloton explosions to estimate the effects of all-out attack with megaton weapons. The same documents circulated in the United States, and were as widely read. Have they been more easily forgotten, obliterated perhaps by more recent traumas? If so, $\mathrm{ABC}$ should show its film again, and then again, for that is what arms control is about.

\section{Wind blows cool}

\author{
Windmills, like wave generators before them, seem \\ to be falling out of favour in Britain.
}

Is the British Government's wind power programme in the doldrums? Earlier this year, the Department of Energy's advisory committee on research and development put wind at the top of the list of renewable sources of energy, saying at the same time that wave power is unlikely to be economic. As a consequence, the department's support for wind power rose by a half to $£ 4.8$ million (1983-84), while wave power fell by two thirds to £1 million. But according to Sir Sam Edwards, newly appointed part-time scientific adviser to Mr Peter Walker, also a new boy as Secretary of State for Energy, one of Sir Sam's first jobs will be to look at the rising cost of big wind turbines such as the department's 55 million, 3-MW station now under construction in the Orkneys, off the coast of Scotland. Nothing has been decided, but there is every chance that wind power will go the way of wave power fairly soon. On paper, windmills look good, but British opinion has cooled as the big American devices have been found to be plagued by problems such as cracked shafts and blades.

There seems also to have been some reassessment among British wind enthusiasts of forecasts of electricity production costs made a few years ago. The most obvious difficulty is that while small machines producing less than $250 \mathrm{~kW}$ peak power have been shown to function reliably, it is agreed that it will be necessary to build machines like the Orkney 60 -m diameter windmill and thus stretch technology to the limit if competitive electricity is to be generated. Sites for windmills are another difficulty, and utility officials are painfully aware that it would be necessary to find 1,000 sites merely to match the output of a single pressurized water reactor. Even with the fuss generated by nuclear proposals, the prospect of 1,000 contentious public inquiries about windmills is daunting.

What, in these circumstances, should the Department of Energy decide? The British nationalized utility, the Central Electricity Generating Board, is building a 4-MW windmill in Kent that will produce electricity at a cost three or four times that of electricity generated in bulk. Replicating that experiment is unlikely to be profitable, for there can be no assurance that the benefits of mass production are anywhere within reach. There is more to be learned from the accumulation of experience with smaller machines in circumstances where they can be used economically for supplying electricity to isolated communities, where their use in Britain is at present inhibited by the antiquated rule that levies local taxes at the rate of 6 per cent of capital cost a year. A modest subsidy, as in the United States, would be more appropriate. Will Mr Walker fight for that? His reputation within the government of which he is a member is that of a liberal; windmills would be an endearing and not too dangerous a cause.

Whether the British Government, with or without help from its new scientific adviser, will be able to chart a future for the industry on whcih the United Kingdom will have to rely for extra electricity generation in the decades ahead is another matter. The decision that the British Government would sanction the building of one nuclear power station a year for the decade now half gone was first announced soon after the general election of 1979. It is true that the demand for electricity has remained obdurately flat since then under the twin influences of economic recession and improved efficiency. But the proposal to build a single pressurized water reactor is still enmeshed in the public inquiry being held in Suffolk. The inquiry will survive robustly into the new year and Mr Walker, if he is lucky, may have moved on to another post before the time comes for the occupant of his post to respond. The difficulty then, of course, will be that of receiving the opinion by the inspector at the inquiry courteously when it is bound to seem that the inquiry has usurped the authority over energy planning that the Department of Energy exists to exercise. To have a few windmills somewhere (though not at $£ 4$ million each) will provide some light relief. 